\title{
Creating artificial Rhino Horns from Horse Hair
}

\author{
Ruixin Mi $\mathbb{B}^{1,2}$, Z. Z. Shao² \& F. Vollrath ${ }^{1 *}$ \\ Demand for rhino horn is driving poaching with devastating effect for the few individuals left of the \\ few species surviving from this once numerous, widespread and cosmopolitan clade of pachyderms. \\ We bundled together tail hairs of the rhino's ubiquitous near relative, the horse, to be glued together \\ with a bespoke matrix of regenerated silk mimicking the collagenous component of the real horn. This \\ approach allowed us to fabricate composite structures that were confusingly similar to real rhino horn \\ in look, feel and properties. Spectral and thermal FT-IR, DSC and TGA analysis demonstrated the similar \\ chemical composition and thermo-mechanical properties between the natural and the faux horns.
}

The horn of the rhinoceros (Rhinocerotidae) is not a horn in the traditional sense like the horn of a cow or the nail of a hoof although it does share some properties ${ }^{1}$. Actually, the rhino's horn is a tuft of hair growing, tightly packed and glued together by exudates from the sebaceous glands, on the nose of the animal ${ }^{2}$. Native rhinoceros horn has been examined in a several key research papers. Of specific importance for our study are Ryder et $a l .{ }^{1}$ who clarify the tubular structure of the keratin hair filaments, Hieronymus et al. ${ }^{3}$ who examine histological sections of horn tissue by $\mathrm{x}$-ray CT-scanning and light microscopy and Ling ${ }^{4}$ who identified rhinoceros horn comparatively through appearance and microstructure. Other studies examine the amino acid composition of different rhino horns ${ }^{5}$ or the composition of their inorganic elements ${ }^{6-9}$. Table 1 compares the rhinoceros horn with a few functionally i.e. compact resistant animal bio-composites.

Rhino survival is critically challenged by the trade in horn, and a range of horn substitutes are being developed and apparently marketed with the ultimate goal of undermining the market in this much sought after if generally banned commodity. Here we offer an economic substitute for rhino-horn fabricated from the tail hair of its near relative, the horse (Equus ferus caballus). As substitute for the sebaceous gland protein exudate cement of the rhino we use a silk-protein based organic filler to glue together the bundled hair. The composite is easily moulded into a horn of hair that is surprisingly similar visually in external and internal micro-structure as well as in feel and overall appearance if shaped and polished.

\section{Results}

The horn of the rhino consists of hairs tightly packed in the bulk of the protuberance and more loosely arranged at the outer shell (Fig. 1). The matrix material filling between the hairs is a very dense packing of cornified dead skin keratocyte cells that can be heavily pigmented with melanin ${ }^{3}$. Melanin is an interesting pigment that not only provides black colour but may also add to a material's structural integrity ${ }^{10}$. Thus the native rhinoceros horn in essence is a composite material, structured by its growth, with the tubules of keratin hair forming 'fibres' that are embedded in a matrix material that may change in composition along and/or across the horn ${ }^{11}$. Throughout the rhinoceros horn each hair filament retains much of its natural hair structure including the medullary cavity although it is lacking the outermost layers of scaly cuticle so typical for external hairs ${ }^{3}$ (Figs 1B,C and 2A,C).

As the key structural material for the manufacture of our artificial rhino horns we used horsetail hair because of its phylogenetic origin (which suggests comparable chemical keratin composition) and its homologous morphological structure (which suggests comparable mechanical properties). Importantly, horsetail hairs also share with rhino horn hairs comparable dimensions, circular symmetry and spongy core structure (Figs 2 and 3 ). In order to copy the key feature separating the two, the lack of the outermost scaly layers in the rhino horn hairs, we used a Lithium Bromide ( $\mathrm{LiBr}$ ) wash to etch and remove the outer layer of the horsehair. We note that this treatment also facilitated the adhesion between the hair fibres and the matrix material that we used.

As there is no detailed information on the composition of the rhino's nose-tip exudate and horn matrix material other than that it seems to be a sebatious gland exudate full of deceased highly melanised cells ${ }^{10}$. Such cells would contain high levels of intra-cellular proteins as well as carrying along the rather adhesive extra-cellular

${ }^{1}$ Department of Zoology, University of Oxford, OX1 3SZ, Oxford, UK. ${ }^{2}$ State Key Laboratory of Molecular Engineering of Polymers, Advanced Materials Laboratory, Fudan University, Shanghai, 200433, China. *email: fritz.vollrath@ zoo.ox.ac.uk 


\begin{tabular}{|l|l|l|l|l|}
\hline Property & $\begin{array}{l}\text { Rhino } \\
\text { horn }\end{array}$ & $\begin{array}{l}\text { Compact } \\
\text { antler }\end{array}$ & $\begin{array}{l}\text { Sheep } \\
\text { Horn }\end{array}$ & $\begin{array}{l}\text { Horse } \\
\text { hoof }\end{array}$ \\
\hline Mid-range tubule density $\left(\mathrm{mm}^{-2}\right)$ & 7 & 36 & 22 & 24 \\
\hline Channel diameter $(\mu \mathrm{m})$ & 100 & 25 & 100 & 40 \\
\hline Porosity $(\%)$ & 6 & 9 & 7 & 3 \\
\hline Work of fracture $\left(\mathrm{MJm}^{-2}\right)$ & 10.0 & 13.9 & 19.6 & 12.0 \\
\hline
\end{tabular}

Table 1. Microstructural features in rhinoceros horn and functionally comparable horn-like bio-materials ${ }^{15-17}$. Note that, in effect, the rhino horn is an all keratin structure and the antler is an all bone structure while the sheep horn is a bone core bearing a keratin sheath and the horse hoof is a keratin nail over a bone base.
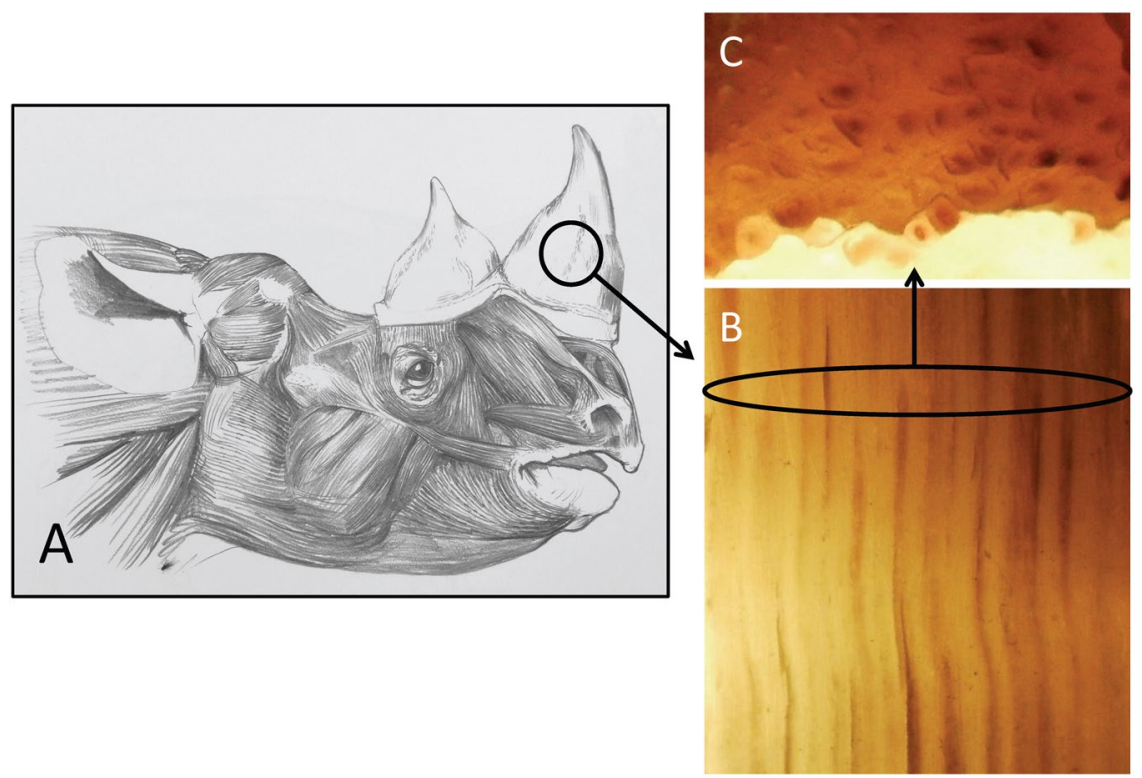

Figure 1. Schematic of Black Rhinoceros (Diceros bicornis) horn showing a section of horn with the hair tubules. The rhino head drawing is by Jonathan Kingdon (reproduced with permission). A single hair is circa $200 \mu \mathrm{m}$ in diameter (length-section B, cross-section C).

fibronectin glycoprotein. Thus the matrix of the native rhino horn would in essence be a largely proteinaceous glue with inclusions of soil and plant sap where the animal has rubbed the growing horn. Assuming such a highly proteinaceous and sticky horn matrix we used for this function in our faux horns the RSF silk fibroin, which we know how to prepare and deploy ${ }^{12}$. Importantly, the RSF material we used can also easily be moulded and cured into a tough matrix to fill-in between the horse-tail hairs.

By bundling the $\mathrm{LiBr}$ washed hairs as tightly as possible while infusing them with the RSF solution we were able to create solid composite cylinders of hair-horn. The smaller horn (around $4 \mathrm{~cm}$ diameter and $10 \mathrm{~cm}$ length) cured within a few days while the largest one (around $12 \mathrm{~cm}$ diameter and $35 \mathrm{~cm}$ length) took weeks in the vacuum oven to dry. The smaller ones, which were our focus for analysis, filed and polished very nicely into surfaces rather similar, indeed confusingly similar, to surfaces of native rhino horn naturally polished by rubbing. If carefully polished a faux horn could thus be easily modified to resemble the outside of a rhino horn. On the microscopic level our Light and Scanning-Electron Microscopy confirmed that not only the gross morphology and anatomy of the faux horn but also the more detailed fine structure was similar to those of real rhino horn.

Importantly for our more fundamental interests in the novel material, rather than the more superficial copying of structures, was the analysis of its material qualities. To this effect we used DSC and TGA to investigate the similarity of the thermal properties between samples of our artificial horns and the real horn.

Differential Scanning Calorimetry (DSC) is a thermo-analytical technique comparing the heat required to increase the temperature of a sample and a reference allowing us to study physical transformations such as phase transitions and determine whether the process is exothermic or endothermic as well as indicating a glass transition. Thermal Gravimetric Analysis (TGA), on the other hand, measures the mass of a single sample as it changes with temperature over time. This data allows us to probe not only physical phenomena such as phase transitions between the solid, liquid and gaseous states of the various components of the material studied but also chemical phenomena such as thermal decomposition and reactions between surfaces.

As shown in Fig. 4(a) the DSC analysis demonstrated that both materials were surprisingly similar with that peaks at $100^{\circ} \mathrm{C}$ indicating the insipient moisture of the samples while the broad endothermic peak from about $200^{\circ} \mathrm{C}$ to $400^{\circ} \mathrm{C}$ indicates the degradation of the protein. The data in Fig. 4 (b) on the other hand, shows that both real and artificial horns started to decompose approximately at $200^{\circ} \mathrm{C}$ with final residues of $1.5 \mathrm{wt} \%$ and $1.3 \mathrm{wt} \%$, respectively. 

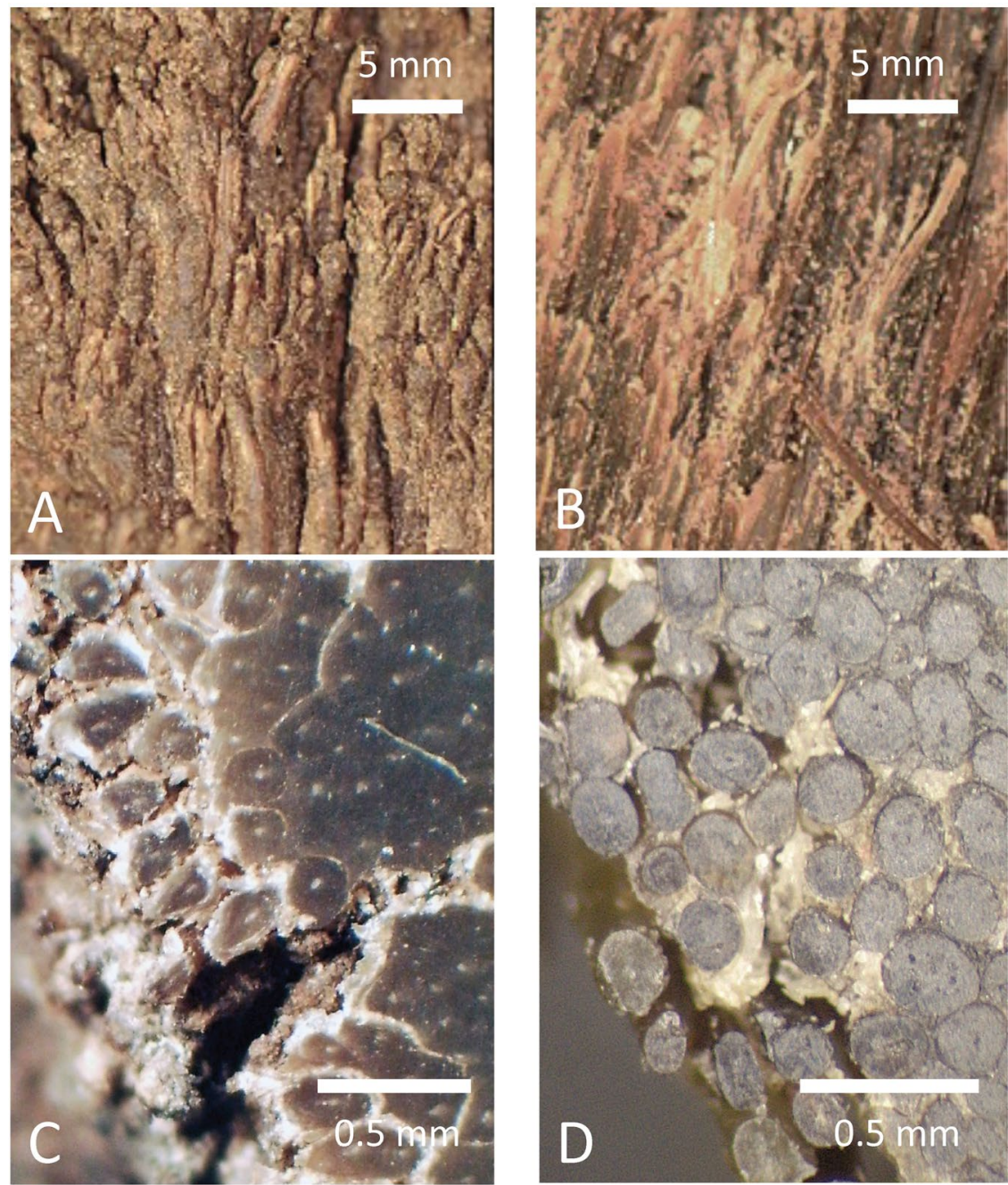

Figure 2. Images of cross-section of a real rhino horn $(\mathbf{A}, \mathbf{C})$ and an artificial horn $(\mathbf{B}, \mathbf{D})$. We note that the hair filament density of our artificial rhino horn is about $9 \mathrm{~mm}^{-2}$, which is close to that $\left(7 \mathrm{~mm}^{-2}\right)$ of real horns ${ }^{11}$.

To further probe the chemical composition and properties of both materials we applied the non-destructive method of FT-IR spectroscopy and compared the absorption bands of key constituent molecules of the both artificial and natural horn material ${ }^{8}$. The absorption bands observed (Fig. 4) at $1650 \mathrm{~cm}^{-1}$ and $3050 \mathrm{~cm}^{-1}$ were assigned to $\mathrm{C}=\mathrm{O}$ stretching and $\mathrm{N}-\mathrm{H}$ stretching. $3270 \mathrm{~cm}^{-1}$ belongs to $\mathrm{O}-\mathrm{H}$ stretching vibration; $1540 \mathrm{~cm}^{-1}$ belongs to $\mathrm{C}=\mathrm{C}$ stretching vibration. $1116 \mathrm{~cm}^{-1}$ was the $\mathrm{S}=\mathrm{O}$ asymmetric stretching, while $1040 \mathrm{~cm}^{-1}$ was the $\mathrm{S}=\mathrm{O}$ symmetric vibrations. $1450 \mathrm{~cm}^{-1}$ and $1240 \mathrm{~cm}^{-1}$ attributed to $\mathrm{C}-\mathrm{H}$ bending and $\mathrm{P}=\mathrm{O}$ stretching. Importantly, samples from both real and artificial horns showed very similar infrared spectra.

Perhaps the most interesting, because mechanically most important, measure of material properties was provided by Dynamic Mechanical Thermal Analysis (DMTA). Here a sample is continuously stress-strained and relaxed by tiny amounts to probe the underlying elastic and plastic properties of a material or composite. In the frequency sweep, samples were tested from $100 \mathrm{~Hz}$ to $0.1 \mathrm{~Hz}$, and under that range materials were still in the liner region (Fig. 4). Thus, in the strain sweep, we applied the force with the frequency of $1 \mathrm{~Hz}$, and the elastic modulus was $1.3 \mathrm{GPa}$, which meets the mechanical properties of natural rhino horns ${ }^{11}$. This similarity between rhinoceros horn and high-performance composites is not surprising; both materials are made up of stiff, inflexible fibres embedded into a flexible resin. The fibres break before they bend while the matrix bends before it breaks. The result is a composite that is able to withstand greater loads than either of its parts. When a stress is applied to the material, the matrix inhibits crack propagation and redistributes stress in the direction of the filaments.

\section{Discussion}

It appears from our investigation that it is rather easy as well as cheap to make a bio-inspired horn-like material that mimics the rhino's extravagantly expensive tuft of nose hair. We leave it to others to attempt to take our technology further and perhaps even go so far as to fool punters into buying it in replacement or indeed in preference to the real, and extremely expensive, rhino horn. Whether flooding the market with confusing horn copies will ultimately lead to saving rhinos roaming in the wild remains to be seen. As material biologists we see few alternatives. It is for conservation economists to examine whether faus horns do work and then to consider whether 

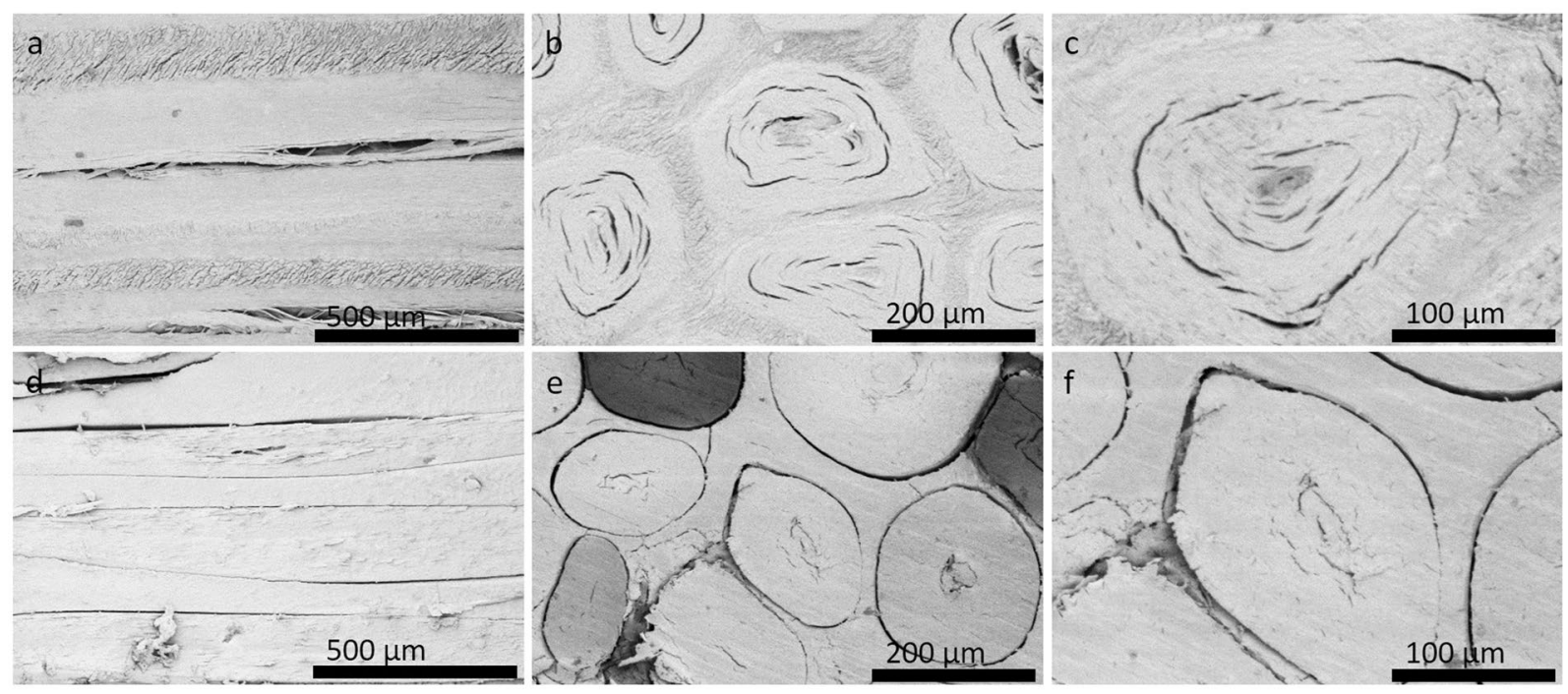

Figure 3. SEM Images of both natural and faux Rhino Hair Horn. The natural horn (upper row) and our faux horn (lower row) show a length section (a,d) and two cross sections in two different magnifications (b,e,c,f). Note that not all hairs are perfectly circular, while their partial disintegration is probably due to vacuum induced dehydration.

driving down the value of rhino horn as described could and would protect the real material and its pachyderm carriers in the wild.

Our artificial silk \& horsetail rhino horn mimic did rather well in our comparative analyses. Optical and Scanning Electron microscopy showed similar outer appearance and inner structure between real and artificial materials. Thermal analysis of both horns showed comparable thermal stability. FTIR showed very similar infrared spectra, which would make it rather difficult (and with a little tweaking perhaps even impossible) to distinguish the artificial horn from its rhino model using a handheld spectrometer.

Mechanical tests confirmed that our artificial copy had mechanical properties similar to the natural original. Thus all together, our results demonstrated that a rather simple composite of horse tail-hair embedded in a silk fibroin matrix can provide a fine biomimetic replacement for real rhinoceros horn. Indeed, hair-silk composites might well find uses well beyond fooling superstition as bio-inspired materials. After all, the fundamental structure of the rhino horn is a highly evolved and tough fibre reinforced bio-composite where the hair fibres provide great tensile strength while the silk-protein matrix provides great ductility.

Perhaps of more interest to the scientist is our observation that our horn impostors have analogous thermal stability and chemical composition demonstrated by FT-IR and TGA analysis. Last but not least, the artificial rhino horn provided us with a model for an interesting artificial fibre-reinforced composite with mechanical properties comparable to those of the natural original evolved over millennia.

\section{Methods}

Regenerated silk fibroin (RSF) solution. The silk fibroin solution was obtained by degumming and $\mathrm{LiBr}$ dissolving skeins of commercial Bombyx mori silk fibres with the solution then and dialyzed to obtain the silk protein compounds according to standard protocols ${ }^{13,14}$ giving a protein concentration of approximately $4 \mathrm{wt} \%$ which was then stored at $4^{\circ} \mathrm{C}$ for further use.

Pre-treatment of horse hair. Natural un-dyed horse tail hair was purchased online. To etch away the outermost dermic-coat layer, the hair was soaked in $\mathrm{LiBr}$ - trialling different concentrations and exposure times for best effect in order to produce hair filaments that most resembled the rhino horn hair, which is lacking outer layers.

Fabrication of silk-based fibre reinforced composites. The pre-treated horse hair was bundled and embedded in the RSF/HPMC solution typically encased in an open Erlenmeyer vial. The soft composite was placed into a vacuum oven to remove the air and heated under $70^{\circ} \mathrm{C}$ for 1 hour. This was followed by soaking in ethanol for 12 hours for ripening and drying in ambient conditions for $48 \mathrm{hrs}$.

Characterization of the artificial horn composite. Scanning electron microscopy (SEM) observation was performed with a TESCAN TS5136 MM at $20 \mathrm{kV}$ of accelerating voltage to image both surface and cross-section after Au-coating for $30 \mathrm{~s}$. Samples were cut by IsoMet slow saw with diamond wafer blade to create smooth surface. Thermogravimetric Analysis (TGA) was performed at $10 \mathrm{~K} \mathrm{~min}^{-1}$ on DTG-60H under air gas with flow rate of $40 \mathrm{~cm}^{3} \mathrm{~min}^{-1}$ at a heating rate of $10^{\circ} \mathrm{C}$ per minute from $50^{\circ} \mathrm{C}$ to $800^{\circ} \mathrm{C}$. Dynamic Scanning Calorimetry (DSC) was performed on small slivers of real rhino horn (legally acquired) and our artificial rhino horn on a TA Q2000 instrument, with a heating rate of $5^{\circ} \mathrm{C}$ per minute from $-50^{\circ} \mathrm{C}$ to $250^{\circ} \mathrm{C}$. For Fourier Transform Infrared (FTIR) 

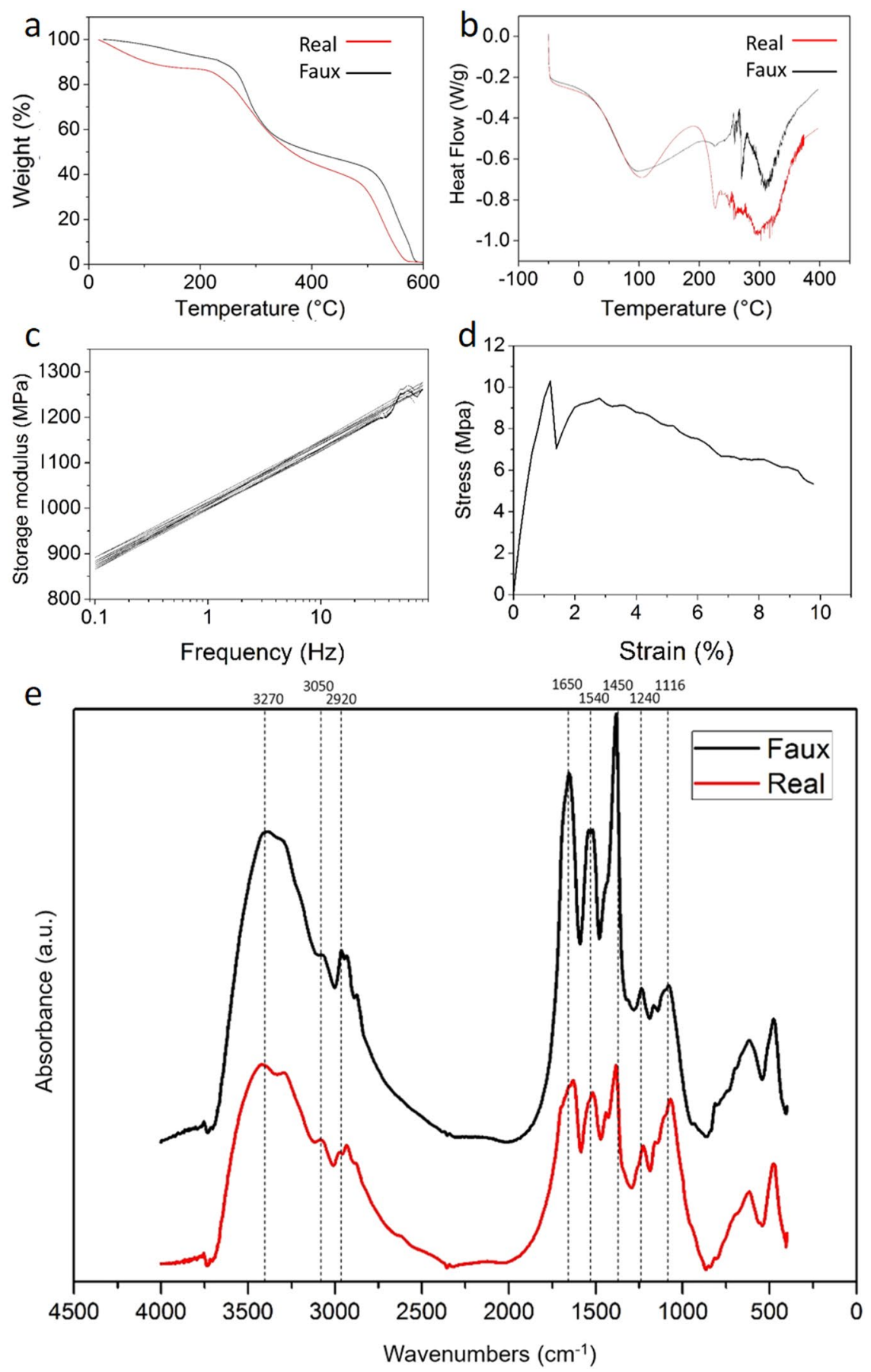

Figure 4. Thermal, spectral and Mechanical testing of the real rhino horns and artificial horn copies. The TGA tests (a), the DSC tests (b), the DMTA frequency sweep (c) and strain sweep (d), the FTIR Spectroscopy result (e).

Spectroscopy the samples were powdered and mixed with $\mathrm{KBr}$, then processed into pellets. The FTIR spectra were obtained with a Nicolet 6700 spectrometer (Thermofisher, the USA) in the range of $650-4000 \mathrm{~cm}^{-1}$ with a resolution of $2 \mathrm{~cm}^{-1}$ for 128 scans. Mechanical Properties were measured using Dynamic Mechanical Thermal Analysis (DMTA) performed on a TA Q800 under DMA multi-frequency strain mode. The constant parameters for all the DMTA tests are as follows: (i) in the frequency sweep, samples were tested from $100 \mathrm{~Hz}$ to $0.1 \mathrm{~Hz}$, (ii) in the strain sweep, we applied the force with the frequency of $1 \mathrm{~Hz}$.

Origin of the native rhino horn samples. The material analysed in detail came from a documented horn of a Black Rhino (Diceros bicornis) collected in 1935 in what was then Southern Rhodesia. This was compared with younger horn material coming from a zoo-bred white Rhino (Ceratotherium simum) that had died more recently. This material was very similar in both fine-grained dimensions and structure but different in colour, 
which would require grey rather than black horse tail hairs for impostor horns. The authors confirm that all methods were carried out in accordance with the relevant guidelines and regulations. The authors also confirm that all experimental protocols were approved by the chair of the licensing committee of the Department of Zoology, University of Oxford, where all the samples resided and were all the testing was done.

Received: 20 June 2019; Accepted: 7 October 2019;

Published online: 08 November 2019

\section{References}

1. Wang, B., Yang, W., Mckittrick, J. \& Meyers, M. A. Keratin: Structure, mechanical properties, occurrence in biological organisms, and efforts at bioinspiration. Progress in Materials Science 76, 229-318, https://doi.org/10.1016/j.pmatsci.2015.06.001 (2016).

2. Ryder, M. L. Structure of Rhinoceros Horn. Nature 193, 1199-\&, https://doi.org/10.1038/1931199a0 (1962).

3. Hieronymus, T. L., Witmer, L. M. \& Ridgely, R. C. Structure of white rhinoceros (Ceratotherium simum) horn investigated by X-ray histology with implications computed tomography and for growth and external form. J Morphol 267, 1172-1176, https://doi. org/10.1002/jmor.10465 (2006).

4. Li, S. Q., Zu, E. D. \& Liu, L. J. Identification of Rhinoceros Horn and its Substitutes. Testing and Evaluation of Inorganic Materials I 177, 636-639, https://doi.org/10.4028/www.scientific.net/AMR.177.636 (2011).

5. Hsieh, H. M. et al. Species identification of rhinoceros horns using the cytochrome b gene. Forensic science international 136, 1-11, https://doi.org/10.1016/S0379-0738(03)00251-2 (2003).

6. Edwards, H. G. M., Hunt, D. E. \& Sibley, M. G. FT-Raman spectroscopic study of keratotic materials: horn, hoof and tortoiseshell. Spectrochim Acta A 54, 745-757, https://doi.org/10.1016/S1386-1425(98)00013-4 (1998).

7. But, P. P., Lung, L. C. \& Tam, Y. K. Ethnopharmacology of rhinoceros horn. I: Antipyretic effects of rhinoceros horn and other animal horns. J Ethnopharmacol 30, 157-168 (1990).

8. Paris, C., Lecomte, S. \& Coupry, C. ATR-FTIR spectroscopy as a way to identify natural protein-based materials, tortoiseshell and horn, from their protein-based imitation, galalith. Spectrochim Acta A 62, 532-538, https://doi.org/10.1016/j.saa.2005.01.023 (2005).

9. Wang, Y. et al. Analysis and identification of different animal horns by a three-stage infrared spectroscopy. Spectrochim Acta A 83, 265-270, https://doi.org/10.1016/j.saa.2011.08.029 (2011).

10. Solano, F. Melanin and Melanin-Related Polymers as Materials with Biomedical and Biotechnological Applications-Cuttlefish Ink and Mussel Foot Proteins as Inspired Biomolecules. Int J Mol Sci 18, https://doi.org/10.3390/Ijms18071561 (2017).

11. Yang, S. A Review of Rhinoceros Horn (2011).

12. Luo, K. Y. \& Shao, Z. Z. A novel regenerated silk fibroin-based hydrogels with magnetic and catalytic activities. Chinese J Polym Sci 35, 515-523, https://doi.org/10.1007/s10118-017-1910-0 (2017).

13. Mi, R. X., Liu, Y. X., Chen, X. \& Shao, Z. Z. Structure and properties of various hybrids fabricated by silk nanofibrils and nanohydroxyapatite. Nanoscale 8, 20096-20102, https://doi.org/10.1039/c6nr07359j (2016).

14. T. Dong, R. M. et al. The regenerated silk fibroin hydrogel with designed architecture bioprinted by its microhydrogel. J. Mater. Chem. B, https://doi.org/10.1039/C9TB00783K (2019).

15. Li, B. W., Zhao, H. P., Feng, X. Q., Guo, W. W. \& Shan, S. C. Experimental study on the mechanical properties of the horn sheaths from cattle. Journal of Experimental Biology 213, 479, https://doi.org/10.1242/jeb.035428 (2010).

16. Mckittrick, J. et al. Energy absorbent natural materials and bioinspired design strategies: A review. Materials Science \& Engineering C 30, 331-342, https://doi.org/10.1016/j.msec.2010.01.011 (2010).

17. Hearle, J. W. A critical review of the structural mechanics of wool and hair fibres. Int J Biol Macromol 27, 123-138, https://doi. org/10.1016/S0141-8130(00)00116-1 (2000).

\section{Acknowledgements}

This project received funding from the American Air Force Office of Scientific Research (AFOSR, FA9550-151-0264), National Natural Science Foundation of China (21574024) and a grant from the China Scholarship Council to R.M.

\section{Author contributions}

F.V. conceived and supervised the project and R.M. prepared and analysed the samples. All authors contributed to the various discussions and the preparation of the manuscript.

\section{Competing interests}

The authors declare no competing interests.

\section{Additional information}

Correspondence and requests for materials should be addressed to F.V.

Reprints and permissions information is available at www.nature.com/reprints.

Publisher's note Springer Nature remains neutral with regard to jurisdictional claims in published maps and institutional affiliations.

Open Access This article is licensed under a Creative Commons Attribution 4.0 International License, which permits use, sharing, adaptation, distribution and reproduction in any medium or format, as long as you give appropriate credit to the original author(s) and the source, provide a link to the Creative Commons license, and indicate if changes were made. The images or other third party material in this article are included in the article's Creative Commons license, unless indicated otherwise in a credit line to the material. If material is not included in the article's Creative Commons license and your intended use is not permitted by statutory regulation or exceeds the permitted use, you will need to obtain permission directly from the copyright holder. To view a copy of this license, visit http://creativecommons.org/licenses/by/4.0/.

(c) The Author(s) 2019 